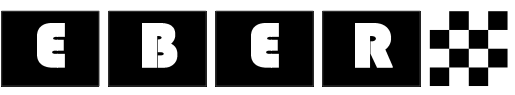

Entrepreneurial Business and Economics Review

2014, Vol. 2, No. 3

\title{
Economic Integration and Foreign Direct Investment: Review of Main Theoretical Concepts
}

\author{
Adam Marszk
}

\section{A B S T R A C T}

Objective: The objective of the article is to present key theoretical relationships between economic integration and FDI flows.

Research Design \& Methods: The research method used is a comprehensive literature review. Most influential publications, including books, articles, working papers, etc. contributing to the subject were identified. The review consists of two essential parts: theory of FDI, and theoretical relationships between economic integration and FDI flows. Finally, the outlined publications were discussed and critiqued, including the empirical context, i.e. empirical verification of the presented links.
\end{abstract}

Findings: In some areas the theoretical impact of integration on FDI is unclear, thus being an obstacle to making informed policy decisions. According to various theoretical concepts, economic integration should influence FDI flows mostly positively, due to e.g. reduced trade barriers and extended market sizes.

Implications \& Recommendations: A number of theoretical concepts support the positive impact of economic integration on FDI flows. Possible directions of future research include comparisons of blocs with members at different development level, and further development of FDI theories in order to account for integration effects.

Contribution \& Value Added: For the time being, this paper seems to be the most comprehensive and up-to-date survey of this topic.

\begin{tabular}{|c|c|}
\hline Article type: & $\begin{array}{l}\text { literature review } \\
\text { economic integration; regional trade agreements; foreign direct } \\
\text { investments (FDI); multinational corporations (MNC); trade }\end{array}$ \\
\hline JEL codes: & F15, F21; \\
\hline Docoind, & Revised: 16 March 2014 \\
\hline
\end{tabular}

\section{Suggested citation:}

Marszk, A. (2014). Economic Integration and Foreign Direct Investment: Review of Main Theoretical Concepts. Entrepreneurial Business and Economics Review, 2(3), 79-89. 


\section{INTRODUCTION}

Over the last few decades, the number of regional trade agreements (RTAs; understood as all forms of integration blocs, including: partial scope agreements, free trade agreements, customs unions and economic integration agreements) has increased rapidly, reaching 377 at the beginning of February 2014 (World Trade Organization, 2014). Despite their important role in the global economy, interdependencies between the economic integration process and foreign direct investment (FDI) flows still remain a relatively neglected research topic, while interactions between economic integration and trade have been studied by numerous authors. An in-depth study of theoretical concepts of linkages between economic integration and FDI seems particularly important, as they form the basis for conducting empirical studies and formulating national and regional policies. However, the current state of knowledge in the field of the integration and investment nexus is assessed by some as unsatisfactory - during the 2013 United Nations Conference on Trade and Development (UNCTAD) multi-year expert meeting on regional integration and FDI, several delegates called for the intensification of such studies and the development of a solid analytical framework (United Nations Conference on Trade and Development, 2013b). Yet another factor increasing the importance of presented topic is the pending negotiations between the United States and the European Union, aimed at creating a Transatlantic Trade and Investment Partnership (TTIP), the world's largest economic bloc. This agreement may have a large impact on FDI flows in the four Visegrad countries, which should be studied carefully and included in the assessment of the agreement's economic consequences.

The main objective of this paper is to present key the theoretical concepts (i.e. conceptual framework) of relationships between economic regional integration and FDI flows. The paper consists of 4 essential parts. The research method which will be used in this article is a theoretical literature review. The summary of theories presented will be based on books, articles, working papers and other papers published in recent years available from various sources, including works accessible through main databases such as ScienceDirect, Springer and Wiley Online Library, as well as the ones published by UNCTAD.

Firstly, the most influential modern theories concerning factors influencing FDI flows will be outlined in order to put the main topic into wider economic and management theory context. The main part of the paper will include a survey of concepts related to linkages between economic integration processes and FDI flows, such as the impact of changes in trade flows caused by intra-regional liberalization on $\mathrm{FDI}$, the impact of more advanced forms of integration (e.g. currency union), and the differences between the effects of integration on intraregional FDI and FDI inflows to the region from external countries.

\section{LITERATURE REVIEW}

\section{Theory of Foreign Direct Fnvestment}

The causes, directions and consequences of FDI flows were studied by many established economists, such as Balassa (the relationships between FDI and market size), Kojima 
(dynamic comparative advantages), Ozawa (FDI and phases of economic development) (letto-Gillies, 2005), but probably the most influential works in the field of FDI theory were published by Dunning, who introduced the concept of the "OLI framework" (also known as the "OLI model" or "eclectic paradigm") (Dunning, 1979, 1980). Some authors divide FDI theories into two wide groups: microeconomic (e.g. the industrialorganization, internalization and product-cycle theories) (Kilic et al., 2014) and macroeconomic (e.g. concepts derived by Kojima and Ozawa); OLI framework is included either in the micro category or in a separate one (Kojima \& Ozawa, 1993). OLI framework will be described as the first concept, then the new theory of FDI, investment development path (IDP) and the gravity model.

According to Dunning's OLI model (Dunning, 1979, 1980), companies (multinational companies, MNCs) undertake FDI when expansion costs are lower than the simultaneously present advantages of three kinds: ownership (O), location (L) and internalization (I) (Bevan \& Estrin, 2004; Di Mauro, 2000). Ownership advantages are both tangible and intangible firm-specific assets, i.e. assets accessible only for a given MNC. Location advantages are linked with features of the market chosen as the location of the MNC's facilities, e.g. factor prices, large customer base, government regulations, trade and investment barriers. Finally, internalization advantages can be used to explain the MNC's decision to undertake FDI and produce goods or provide services internally instead of other forms of foreign expansion such as licensing or franchising - reasons for internalization include the reduction of transaction costs and informational asymmetries, as well as avoiding misuse of valuable knowledge assets.

Due to observed deficiencies of the OLI framework (failure to explain FDI trends in the late 1980s and early 1990s), new approaches were introduced by (among others) Helpman, Krugman and Brainard, formulating "the new theory of FDI" that merged OLI framework with general equilibrium models (Bevan \& Estrin, 2004).

In order to gain insight into the modified FDI theories, it is necessary to define the distinction between vertical and horizontal FDI (Athukorala, 2013). Vertical FDI are efficiency-seeking investments in the form of a geographical fragmentation of the production process aimed at using location-specific (" $L$ " in the OLI framework) advantages. Horizontal FDI are market-seeking and involve producing the same goods (providing the same services) in many countries, thus avoiding foreign trade, e.g. export, costs. Costs in the first of the strategies mentioned above (vertical) are mostly coordination costs and in the second (horizontal) include foregoing benefits of economies of scale.

Early new theory of FDI models focused on vertical FDI. According to the HelpmanKrugman model, companies' foreign activities and the creation of multinational companies are spurred by the tendency of factor rewards to differ between countries (Helpman \& Krugman, 1985). Later models accounted for horizontal FDI - in Brainard's model companies choose between exporting and related advantages, such as scale economies at the plant and firm level (e.g. R\&D expenses), and proximity to the foreign market (Brainard, 1993). When proximity and market-access advantages outweigh the concentration ones, horizontal FDI takes place (Di Mauro, 2000).

In contrast with earlier concepts, the last two of the general FDI theories may be included in the macroeconomic category, despite some elements of the eclectic 
paradigm. In IDP theory, based on the OLI framework, the FDI flows respond to the structural changes resulting from economic development (economic development and economic growth are treated here as synonyms) (Dunning \& Narula, 1996; Narula \& Guimón, 2010). The core of IDP framework is made up of dynamic interactions between FDI and the changes in ownership advantages of domestic companies, the ownership advantages of MNCs and the location advantages of countries ("O", "O" and " $\mathrm{L}$ "). The development path of countries is divided into five stages, with varying location advantages - the higher the development level, the lower the importance of factor prices advantages and the higher the importance of intangible resources. Due to differing ownership and location advantages at various stages of economic development, the magnitude of FDI inflows and outflows changes, resulting in varying net outward investment (NOI) positions. The usual NOI pattern suggested by authors is negative at early stages and positive at later stages; however, authors stress that each country's path is unique and dependent upon its size, population, natural resources, political situation and many others (Narula \& Guimón, 2010).

The gravity FDI model is based on similar models used in studies on international trade and may be regarded as a synthesis of various types of new theory of FDI models (Di Mauro, 2000), and, consequently, as the most extensive FDI analytical framework. Despite differences between various specifications of gravity FDI models resulting from varying assumptions, there are some common features, described e.g. in Bevan \& Estrin (2004). According to the gravity approach, the decision of MNC to undertake FDI depends on two contrasting factors: the costs of investing abroad (e.g. building a new plant) and costs linked with exporting from the domestic country, both measured in terms of relative market sizes and either the absolute or relative distance between them. The market sizes of domestic and host economies are measures of potential demand, growth and supply capacity. Within this framework, distance is the main factor influencing the transaction costs of foreign expansion, such as transportation or informational costs of legal and institutional factors (e.g. local tax systems). Other variables included in these models are used to account for differences in relative labor and capital endowments (and their costs), economic and political risk, or institutional development. Gravity FDI models are also modified in order to more accurately capture changes resulting from economic integration. Such alterations will be described in the next section.

\section{Theoretical Links between Economic Integration and Foreign Direct Investments}

Before exploring the various theories concerning links between economic integration and FDI flows, it is necessary to state that a high level of heterogeneity of both integration blocs and FDI is a significant barrier to formulating general statements. However, the presented interdependencies may be grouped into a few categories. In this section of the paper, theories concerning the abovementioned links will be described using two approaches: firstly, in terms of the economic integration effects, and, secondly, with regard to the various analytical frameworks, including the ones outlined in the previous section. In the final paragraph of this section, in contrast to earlier parts, the reverse causality links will be briefly described, i.e. the contribution of FDI to regional integration. 
Economic integration is a process with far-reaching implications for many areas of the bloc's economies and, consequently, for the flows of outward and inward FDI. For the purposes of this paper, we divided these mechanisms into the following groups (Table 1; due to insufficient data FDI outflows from the bloc to non-member countries were omitted).

Table 1. Expected impact of the mechanisms of economic integration on foreign direct investment flows

\begin{tabular}{|c|c|c|}
\hline \multirow{2}{*}{ Mechanism } & \multicolumn{2}{|c|}{ Type of FDI flows } \\
\cline { 2 - 3 } & intraregional & $\begin{array}{c}\text { inflows to region from non- } \\
\text { member countries }\end{array}$ \\
\hline $\begin{array}{c}\text { the reduction of intraregional trade barriers } \\
\text { (tariffs and non-tariffs); trade and } \\
\text { investment treated as complements }\end{array}$ & positive (mostly for vertical) & $\begin{array}{c}\text { positive (mostly for } \\
\text { horizontal) }\end{array}$ \\
\hline $\begin{array}{c}\text { the reduction of intraregional trade barriers } \\
\text { (tariffs and non-tariffs); trade and } \\
\text { investment treated as substitutes }\end{array}$ & negative & negative \\
\hline $\begin{array}{c}\text { creation of a customs union } \\
\text { enlarged markets }\end{array}$ & as above \\
\hline (positive/negative) & $\begin{array}{c}\text { depends on differences in } \\
\text { member and non-member } \\
\text { countries }\end{array}$ \\
\hline provisions & positive & positive \\
\hline $\begin{array}{c}\text { investment liberalization and protection } \\
\text { economic growth }\end{array}$ & positive & positive \\
\hline increased efficiency and accelerated & mostly positive & mostly positive \\
\hline
\end{tabular}

Source: own elaboration based on (Medvedev, 2012; UNCTAD, 2013a).

The theoretical effects of trade liberalization on FDI flows remain unclear and depend on whether trade and investment are considered to be complements or substitutes. In the first case, establishment of RTAs is expected to increase vertical intraregional FDI flows due to the rising complexity of MNCs' production networks (and their creation costs), as well as to the minimum level of trade links necessary for FDI to emerge (Medvedev, 2012; Witkowska, 2001); another important factor is cost differentials (Kubny et al., 2011). Horizontal FDI inflows from countries outside the RTA may also increase because of the establishment of so-called export platforms served earlier by trade - such flows are analyzed using export-platform FDI models (Velde \& Bezemer, 2006). On the other hand, in this process, existing pre-integration extensive sales and/or production networks may be consolidated, thus reducing total external FDI stock in the bloc. According to early concepts (based on the assumption of trade-investment substitutability), creating an economic bloc was expected to decrease the magnitude of FDI flows (or increase FDI flows in the form of divestments) - horizontal FDI flows should decrease due to the lower costs of serving foreign markets through trade than affiliates (reduction of "tariff-jumping" FDI) (Witkowska, 2001).

Conducting an analysis of the consequences of the creation of customs unions for FDI flows requires an extension of the framework presented above, particularly when FDI 
flows between members and non-members are considered. In the case of introduced or potentially higher levels of outside protection, horizontal FDI inflows from external countries should increase as a result of greater incentives for MNC to undertake "tariffjumping" FDI and concentrate their production in member countries with the lowest costs (Chen, 2009). The scale of such capital flows depends on the differences between tariffs and other trade barriers applicable to member and non-member countries (Athukorala, 2013). However, a growing number of customs unions combine intraregional and external trade liberalization which may have the opposite effect, increasing vertical FDI and decreasing horizontal FDI attractiveness for external MNCs.

The creation of an economic bloc leads to increased market size, which in turn influences the magnitude of FDI flows. This effect is strongest in larger economic blocs and in countries belonging to multiple agreements (Chen, 2009). The positive impact of increased market size on FDI flows is regarded in the literature as well established (Medvedev, 2012). The main underlying mechanism is the possibility to exploit the economies of scale in three significant ways (Athukorala, 2013): large plants manufacturing one product, horizontal specialization (decreased number of product varieties manufactured in plants) and vertical specialization (manufacturing parts and accessories of a single product in various locations). Yet another mechanism is the increased international merger and acquisition activity caused by competitive pressure from a larger number of companies (Medvedev, 2012).

Investment liberalization and protection provisions within economic blocs are directly linked to decisions to undertake FDI made by MNC due to the reduced transaction costs (Kubny et al., 2011). Such rules include lifting investment restrictions (i.e. opening various sectors to foreign investors), dispute settlements (e.g. FDI provisions in the North American Free Trade Agreement (Marszk, 2010)), and the harmonization of FDI policies that lower political risk and improve investment climate, making it also more predictable. If changes in regulations are significant, intraregional FDI flows should increase and the inflows of FDI from outside the region, both from new and established investors, should rise as well. Moreover, members of the bloc may decide to introduce measures aimed at promoting FDI e.g. preferential tax treatments (Velde \& Bezemer, 2006).

The next category of the potential regional integration's impact on FDI is linked to the dynamic effects of this process, mainly to the higher degree of competition, higher efficiency of resource allocation and accelerated economic growth. While the relationship between FDI flows and economic growth seems to be positive (the direction of causality is, though, problematic, e.g. FDI through technology transfers may further boost growth) (Medvedev, 2012), other linkages are more complicated, e.g. stronger domestic companies can decrease the attractiveness of a given market among foreign investors, but more efficient firms becoming regional leaders should undertake vertical FDI (Velde \& Bezemer, 2006) inside the bloc, and horizontal as well as vertical FDI in external countries.

The impact of monetary integration within an economic bloc on FDI flows is linked by and large to the elimination of the exchange rate variability inside the region (Petroulas, 2007). By reducing related transaction costs, monetary integration should boost FDI flows. However, Di Mauro (2000) argued that the net impact on FDI is unclear 
- before the creation of a monetary union MNCs prefer to open affiliates in member countries (through FDI) in order to avoid the exchange rate risk, whereas its establishment makes exporting, not FDI, a more attractive option (if trade and FDI are substitutes). Another mechanism of monetary integration's impact on FDI is the proceeding financial integration of the union's countries. Potential positive influences include the reduction of macroeconomic instability, coordinated response to common shocks, as well as increased transparency and policy credibility (Sousa \& Lochard, 2006), whereas the higher speed of economic turbulences transmission may decrease FDI flows (Folfas, 2012).

One of the main analytical concepts concerning economic integration's (in the following paragraphs, the forms of integration analyzed are customs unions and more advanced stages) impact on FDI flows is the distinction between investment creation and diversion (analogically to trade creation and diversion occurring during integration processes) (Kreinin \& Plummer, 2008). Investment creation is an increase in the volume of FDI inflows from non-member countries due to trade diversion effects, and investment diversion is FDI flows between member countries in response to trade creation effects which require production reorganization (Kindleberger, cited in Witkowska, 2001). Kreinin \& Plummer (2008) defined the abovementioned effects in a different way: investment creation is understood as foreign investments substituting domestic ones undertaken in order to benefit from lower production costs (causing the reconfiguration of resources allocation, making it more efficient), and investment diversion as lowering the FDI inflows from member countries to non-member ones and redirecting them to locations inside the bloc due to tariff discrimination (with a negative impact on global welfare because of reduced investment in more efficient countries).

Within the OLI framework, the establishment of customs union influences mostly location ("L") advantages because of changes in external trade policies (Kreinin \& Plummer, 2008). For MNCs from both member and non-member countries, FDI inside the union enables the achievement of higher location advantages, resulting from dynamic integration processes such as the reorganization of production or intensified competition (Witkowska, 2001). In the course of these processes, new location advantages are revealed (e.g. decreased transport costs) and FDI are undertaken to seek optimum location. However, in the case of "tariff-jumping," FDI location advantages may diminish due to the increased attractiveness of exporting instead of opening foreign affiliates.

Economic integration can also have a significant impact on ownership ("O") advantages (Witkowska, 2001) because of its dynamic effects. For MNCs from member economies, integration provides access to extended markets and the possibility of exploiting the economics of scale, therefore enabling the companies to increase R\&D spending and gain new or boost current ownership advantages. For MNCs from outside the bloc, it is necessary to have some initial ownership advantages in order to compete with internal (i.e. domiciled in the bloc) competitors, and accumulate such advantages.

The effects of economic integration may also be incorporated into macroeconomic FDI theories. The dynamic effects affect economic development and, consequently, FDI flows within the IDP framework. Gravity FDI models were also modified by extending their specification and including variables such as the level of tariffs and non-tariff 
barriers, exchange rate variability (in the case of monetary integration) and measures of political integration (e.g. changes in corruption level, with the assumption of a positive impact of some integration aspects) (Di Mauro, 2000).

An important element of the analysis of links between economic integration and FDI (here: the impact of integration on FDI flows) is the spatial distribution of FDI - integration may increase the total FDI inflow to the bloc from external countries, but the effects in individual countries may be insignificant or even negative (Velde \& Bezemer, 2006). Relocation and agglomeration effects may lead to efficiency gains at a regional scale due to economies of scale, thus boosting further relocation processes. They may affect the convergence of economies within the bloc and, therefore, also the FDI flows. Countries outside the bloc may decide to enter it, becoming part of clusters in order to increase their attractiveness among foreign investors.

In the previous paragraphs of this section, the causality of links described ran from economic integration to FDI flows. However, the direction of causality is difficult to establish because, on the one hand, FDI flows depend on a number of factors, and, on the other hand, FDI can enable and change the character of integration processes (Ładyka, 2001; United Nations Conference on Trade and Development, 2013a). Increased FDI flows between member countries can spur development and the intensification of trade flows (if FDI and trade are complementary), and, in long term, economic growth and employment (Witkowska, 2001). Another group of FDI affecting growth prospects positively is reorganization and rationalized FDI (Yannopoulos, cited in Robson, 1998). Reorganization FDI causes the reallocation of foreign activity, usually in fewer affiliates, according to countries' comparative advantage (they also reduce adjustment costs in the block (Ładyka, 2001)). Rationalized FDI are undertaken to take advantage of differences in factor costs and their inflow to the bloc should increase due to the lowering or elimination of trade barriers (Yannopoulos, cited in Robson, 1998). Nevertheless, for countries with MNCs which benefit at large from integration (e.g. by accumulating ownership advantages), it may lead to negative net FDI flows (outflows higher than inflows) and lower employment (Witkowska, 2001). FDI are also crucial for countries with insufficient capital and low technology levels as they may be used (under certain conditions, outside the scope of this paper) to overcome these growth barriers.

\section{DISCUSSION}

FDI theory has been developed from the OLI framework, through early new theories of FDI, to gravity FDI models, based on established concepts and models used in studies on trade flows (another important theory is the IDP framework). Some of the presented FDI theories focused on microeconomic aspects (decisions and activities of companies), whereas others focused on macroeconomic aspects (e.g. IDP framework). Despite the growing number of publications on the relationship between economic integration and FDI, the current state of knowledge in this field is assessed by some, as mentioned in the introduction, as insufficient. Particularly significant for policymakers are areas in which the theoretical impact of integration on FDI flows is unclear, thus being an obstacle to making decisions to intensify the integration processes (e.g. effects of monetary integration). On the whole, however, according to the various theoretical concepts outlined, economic integration should influence FDI flows mostly positively, due to e.g. 
reduced trade barriers, extended market sizes and dynamic effects. Similarly, FDI flows are expected to spur economic integration.

As far as TTIP (i.e. potential USA-EU economic bloc, with V4 countries' participation) is concerned, based on the analytical frameworks described in the third section, one should expect strong increases in intraregional vertical FDI flows (mechanism outlined in: Athukorala, 2013). Such flows should occur because of complementary economic structures of less-developed and highly-developed members of the suggested agreement (e.g. increased FDI flows between USA and East European EU members), enabling intra-industry specialization. Another related factor which should boost FDI flows is relative differences in labor and capital endowments (and their costs), as well as reforms and reorganization undertaken on both a micro (e.g. in companies) and macro (e.g. economic policy) scale in order to sustain or gain competitive advantage.

There have been many attempts (but much less for FDI than trade) at empirically verifying the theoretical links presented in the third section (a review of such studies may be found in: Baltagi et al., 2008; Medvedev, 2012; Velde \& Bezemer, 2006). They generally support the positive influence of the creation of economic blocs on FDI flows. Individual mechanisms have been studied to a varying extent (Medvedev, 2012). While basic channels, i.e. trade liberalization, increased market size and investment provisions, are supported by a few studies, dynamic effects are omitted due to problems with the correct selection of determinants (Medvedev, 2012). However, according to Dunning (Dunning, cited in: Kubny et al., 2011), the impact of economic integration on FDI is very complex and it is almost impossible to isolate the effects of integration (another obstacle is their typically indirect character). Therefore, the results of empirical studies should be analyzed with caution. Moreover, because of problems with the correct specifications of econometric models (linked with the issues described above), case studies of selected blocs seem to be a more plausible solution (Kubny et al., 2011; United Nations Conference on Trade and Development, 2013a).

\section{CONCLUSIONS}

This paper includes a survey of significant, selected FDI theories and an overview of the potential links between economic integration and FDI flows, together with possible modifications of the main FDI theories to account for such relationships. A number of theoretical concepts support the positive impact of economic integration on FDI flows. However, distinction between intraregional FDI flows and flows between non-member and member countries must be made as the suggested FDI motives and direction of flows may differ. The effects of FDI flows on economic integration are expected to be positive; analytical framework concerning this issue is, however, relatively underdeveloped and, to the best of our knowledge, has not been empirically verified.

The main limitation of this paper is the limited number of FDI theories presented an in-depth study of a larger body of literature on FDI theoretical determinants, as well as an extended survey of empirical research may be the subject of future research. Such a study may include a comparison of the analyzed effects in blocs at different stages of integration or blocs with members at different levels of economic development, e.g. with developing countries or developed countries only, contrasted with the ones grouping both categories of countries. Furthermore, despite some modifications of the main FDI 
theories, the potential effects of economic integration on FDI were to a very limited degree included in the theoretical deliberations. Further development and modification of FDI theories by introducing the elements accounting for integration effects may also be addressed in future papers.

\section{REFERENCES}

Athukorala, P. C. (2013). Intra-regional FDI and economic integration in South Asia: trends, patterns and prospects. Retrieved on February 3, 2014 2014, from http://unctad.org/en/Publications Library/ecidc2013misc1_bp7.pdf

Baltagi, B. H., Egger, P., \& Pfaffermayr, M. (2008). Estimating regional trade agreement effects on FDI in an interdependent world. Journal of Econometrics, 145(1-2), 194-208.

Bevan, A. A., \& Estrin, S. (2004). The determinants of foreign direct investment into European transition economies. Journal of Comparative Economics, 32, 775-787.

Brainard, S. L. (1993). A simple theory of multinational corporations and trade with a trade-off between proximity and concentration. NBER Working Paper. Retrieved on February 1, 2014, from http://www.nber.org/papers/w4269.pdf

Chen, M. X. (2009). Regional economic integration and geographic concentration of multinational firms. European Economic Review, 53, 355-375.

Di Mauro, F. (2000). The Impact of Economic Integration on FDI and Exports: A Gravity Approach. Centre for European Policy Studies Working Documents. Retrieved on January 19, 2014 from http://aei.pitt.edu/11687/1/66.pdf.

Dunning, J. H. (1979). Explaining changing patterns of international production: in defence of the eclectic theory. Oxford Bulletin of Economics and Statistics, 41(4), 269-295.

Dunning, J. H. (1980). Toward an eclectic theory of international production: some empirical tests. Journal of International Business Studies, 11, 9-31.

Folfas, D. (2012). Does Monetary Integration Affect FDI between EU Member States. Retrieved on February 1, 2014, from http://www.etsg.org/ETSG2012/Programme/Papers/301.pdf

Helpman, E., \& Krugman, P. (1985). Market Structure and Foreign Trade: Increasing Returns, Imperfect Competition, and the International Economy. Cambridge: MIT Press.

letto-Gillies, G. (2005). Transnational Corporations and International Production: Concepts, Theories and Effects. Cheltenham \& Northampton: Edward Elgar Publishing.

Kilic, C., Bayar, Y., \& Arica, F. (2014). Effects of Currency Unions on Foreign Direct Investment Inflows: The European Economic and Monetary Union Case. International Journal of Economics and Financial Issues, 4(1), 8-15.

Kojima, K., \& Ozawa, T. (1993). Micro- and Macro-Economic Models of Direct Foreign Investment: Toward a Synthesis. In H. P. Gray (Ed.), Transnational Corporations and International Trade and Payments (pp. 63-85). New York: Routledge.

Kreinin, M. E., \& Plummer, M. G. (2008). Effects of regional integration on FDI: An empirical approach. Journal of Asian Economics, 19(5-6), 447-454.

Kubny, J., Mölders, F., \& Nunnenkamp, P. (2011). Regional integration and FDI in emerging markets. In U Volz (Ed.), Regional Integration, Economic Development and Global Governance (pp. 172-206). Cheltenham \& Northampton: Edward Elgar Publishing.

Ładyka, S. (2001). Z teorii integracji gospodarczej. Warszawa: Szkoła Główna Handlowa w Warszawie. 
Marszk, A. (2010). Północnoamerykańskie Porozumienie o Wolnym Handlu (NAFTA) i jego postanowienia dotyczące bezpośrednich inwestycji zagranicznych [North American Free Trade Agreement (NAFTA) and its regulations concerning foreign direct investment]. Ekonomia Międzynarodowa, 1(1), 67-85.

Medvedev, D. (2012). Beyond trade: the impact of preferential trade agreements on FDI inflows. World Development, 40(1), 49-61.

Narula, R., \& Guimón, J. (2010). The investment development path in a globalised world: implications for Eastern Europe. Eastern Journal of European Studies, 1(2), 5-19.

Petroulas, P. (2007). The effect of the euro on foreign direct investment. European Economic Review, 51(6), 1468-1491.

Robson, P. (1998). The Economics of International Integration. New York: Unwin Hyman/Routledge.

Sousa de, J., \& Lochard, J. (2006). Does the single currency affect FDI? A gravity-like approach. Retrieved February 5, 2014, from http://www.fm-kp.si/Files/File/Konference/EIIE\%202006/ deSousa.pdf

United Nations Conference on Trade and Development. (2013a). Regional integration and foreign direct investment in developing and transition economies. Retrieved on February 5, 2014, from http://unctad.org/meetings/en/SessionalDocuments/ciimem4d2_en.pdf

United Nations Conference on Trade and Development. (2013b). Report of the Multi-year Expert Meeting on Investment, Innovation and Entrepreneurship for Productive Capacity building and Sustainable Development on its first session. Retrieved on February 5, 2014, from http://unctad.org/meetings/en/SessionalDocuments/ciimem4d3_en.pdf

Veldete, D. W., \& Bezemer, D. (2006). Regional integration and foreign direct investment in developing countries. Transnational Corporations, 15(2), 41-70.

Witkowska, J. (2001). Rynek czynników produkcji w procesie integracji europejskiej [Production factors market within the European integration process]. Łódź: Wydawnictwo Uniwersytetu Łódzkiego.

World Trade Organization. (2014). Some Figures on Regional Trade Agreements notified to the GATT/WTO and in force. Retrieved on February 5, 2014, from http://rtais.wto.org/UI/publics ummarytable.aspx

\title{
Author
}

\section{Adam Marszk}

Assistant at the Faculty of Management and Economics of Gdansk University of Technology. Master's Degree from Warsaw School of Economics and PhD in economics from Gdansk University of Technology.

\author{
Correspondence to: \\ Adam Marszk, PhD \\ Gdansk University of Technology \\ Faculty of Management and Economics \\ Department of Economics \\ ul. Narutowicza 11/12, 80-233 Gdańsk, Poland \\ adam.marszk@zie.pg.gda.pl
}


